\title{
РОЗВИТОК ЛЮДСЬКИХ РЕСУРСІВ ТА ОРГАНІЗАЦІЙНОЇ КУЛЬТУРИ В ДЕРЖАВНИХ ОРГАНАХ: ВИКОРИСТАННЯ МЕТОДОЛОГІЇ ДИЗАЙН-МИСЛЕННЯ
}

\section{DEVELOPMENT OF HUMAN RESOURCES AND ORGANIZATIONAL CULTURE IN PUBLIC AUTHORITIES: USING THE DESIGN THINKING METHODOLOGY}

\begin{abstract}
У статті запропоновано заходи з фрормування організаційної культури, сприятливої для розвитку людських ресурсів у державних органах, реалізація яких передбачає запровадження HR-брендингу, систем навчання і розвитку персоналу (зокрема, програм розвитку талантів), гнучких умов роботи, програм добробуту працівників, нових систем винагород тощо. З урахуванням досвіду розвинених країн, які для пришвидшення змін у структурах урядів або HR-агентств створили дизайн-лабораторії (чентри досконалості), обгрунтовано доцільність використання методології дизайн-мислення, розкрито ї складові частини та принципи. Запропоновано адаптовану схему процесу використання методології дизайн-мислення для вирішення проблеми низької ефрективності системи навчання і розвитку персоналу в державних органах. Реґламентований ітераційний процес реалізується 3 використанням таких методів, як: матричя відомого й усвідомленого, дерево проблем, метод "5W", інтерв'ювання, обстеження, «карта емпатії» та «карта подорожі» працівників, сторітеллінг, кластеризація інорормації, мозковий штурм, дискусія, ранжування, моделювання, експеримент. Алгоритм використання методологіі дизайн-мислення обговорено із прачівниками Міністерства юстиції України у вересні 2020 року під час проведення вебінарів із питань запровадження змін та управління персоналом. Результати онлайн-опи тування 96 слухачів у програмі Mentimeter засвідчили підтримку державними службовцями категорій «Б» та «В» запровадження методології дизайн-мислення, незважаючи на такі бар'єри, як бюрократія, низький рівень мотивації та готовності персоналу державних органів до змін, відсутність лідерів та необхідних знань, брак часу, недостатність фрінансування тощо. Тому з метою реалізації пілотного проєкту Івано-Франківський національний технічних університет нафтти $і$ газу ініціює створення дизайн-лабораторії "LIDER" (Лабораторія інтелектуального розвитку для посилення спроможності регіонів) на базі Інституту гуманітарної підготовки та державного управління.
\end{abstract}

Ключові слова: розвиток персоналу, людиноцентризм, дизайн-лабораторія, запровадження змін, державні службовці.

The article proposes measures to form an organizational culture conducive to the development of human resources in public authorities, the implementation of which involves the introduction of HR-branding, systems of personnel training and development (including talent development programs), flexible working conditions, employee welfare programs, new reward systems, etc. The expediency of using the design thinking methodology is substantiated, as well as its components and principles are revealed taking into account the experience of developed countries which have created design laboratories (centers of excellence) in the structures of governments or HR agencies to accelerate changes. The adapted scheme of the process of using the design thinking methodology to solve a problem of low efficiency of the system of personnel training and development in public authorities is offered. The determined iterative process is implemented using the following methods: matrix of knowledge and awareness, problem tree, method " 5 W", interviews, observation, "empathy map" and "journey map" of employees, storytelling, information clustering, brainstorming, discussion, ranking, modeling, experiment. The algorithm for using the design thinking methodology was discussed with personnel of the Ministry of Justice of Ukraine in September 2020 during webinars on change implementation and personnel management. The results of 96 participants' online survey using the Mentimeter program showed the support of civil servants of categories " $B$ " and " $C$ " for the introduction of the design thinking methodology in public authorities despite the following barriers: bureaucracy, low level of motivation and readiness of civil servants for changes, lack of leaders and necessary knowledge, lack of time and funding. Therefore, in order to implement the pilot project, the Ivano-Frankivsk National Technical University of Oil and Gas initiates the creation of a design laboratory "LIDER" (Laboratory of Intellectual Development for Empowering Regions) on the basis of the Institute of Humanities and Public Administration.

Key words: personnel development, human-centrism, design laboratory, changes implementation, public servants.
Постановка проблеми в загальному вигляді. Найважливішими чинниками розвитку інституційної спроможності державних органів є їхні людські ресурси й організаційна культура, яка являє собою модель ключових цінностей, переконань, уявлень і норм, спільних для персоналу. Метою розвитку організаційної культури є формування середовища та 
командного духу, сприятливих для досягнення цілей державного органу та покращення його діяльності, забезпечення прихильності персоналу й іміджу «хорошого роботодавця». Адже в результаті емпіричних досліджень закордонні науковці довели позитивний вплив організаційної культури на показники, які свідчать про успіх організації, зокрема продуктивність, покращення якості послуг, утримання працівників тощо [1]. На думку експертів компанії «ПрайсвотерхаусКуперс», інноваційні культура та поведінка, креативне мислення та лідерство є важливішими, ніж зрозуміла стратегія та бюджет організації [2, с. 16].

На жаль, в Україні донині моніторинг та системні дослідження розвитку людських ресурсів та організаційної культури в державних органах не здійснювались, але про наявні проблеми свідчать, зокрема, результати опитувань працівників центральних і територіальних органів виконавчої влади, які проводить Національне агентство України з питань державної служби. Зокрема, у 2019 р. виявлено, що 66\% респондентів із понад 1000 опитаних державних службовців стикались із булінгом на роботі щодо себе [3]. Це негативно впливає на рівень задоволення від роботи, їхню мотивацію, прихильність до відповідного державного органу, «клімат» на робочому місці та, зрештою, на продуктивність праці. Водночас модернізовані служби управління персоналом державних органів, які здійснюють підготовку та реалізацію ключових національних реформ, найбільше часу (31\%) витрачали на документальне оформлення вступу на державну службу, її проходження та припинення та найменше $(7,8 \%)$ - на здійснення аналітичної й організаційної роботи з кадрового менеджменту [4].

Аналіз останніх досліджень і публікацій. Проблеми формування організаційної культури, сприятливої для розвитку людських ресурсів в органах державної влади й органах місцевого самоврядування, досліджували Н. Алюшина, Т. Василевська, Л. Воронько, В. Князєв, А. Ліпенцев, Т. Маматова, Н. Нижник, Л. Пашко, А. Рачинський, В. Толкованов, Н. Щербак та інші вітчизняні науковці. Вони розкрили сутність та види організаційної культури, їі роль у підвищенні рівня професійної компетентності публічних службовців, проблеми й особливості формування організаційної культури в державних органах, дослідили інструменти її розвитку та запропонували шляхи адаптації закордонного досвіду в цій сфері.

Виділення не вирішених раніше частин загальної проблеми. Однак унаслідок пан- демії COVID-19 зміни у сфері управління людськими ресурсами, які розглядались як стратегічні, довгострокові, стали раптовими, реактивними, а сформована організаційна культура виявилась недостатньо ефективною для запровадження змін та інновацій.

Метою статті є обґрунтування доцільності використання методології дизайн-мислення як ефективної людиноцентричної соціальної технології для формування організаційної культури, сприятливої для розвитку людських ресурсів у державних органах.

Виклад основного матеріалу. Організаційна культура $€$ унікальною для кожної організації складною системою, у формуванні якої визначальними є такі три параметри: 1) відносини між співробітниками і самою організацією; 2) вертикальна структура ієрархії, що визначає взаємини між керівництвом організації й іншими співробітниками; 3) уявлення працівників про місію організації, цілі, завдання та свою власну роль у її діяльності [5, с. 69]. Однак у сучасній літературі немає єдиного підходу до визначення типів організаційної культури та їх характеристики. Адже, крім особистісних, соціальних, національних та географічних чинників, на тип організаційної культури впливають ще й технічні, економічні, професійні та політико-правові чинники. Це призводить до того, що на практиці складно чітко ідентифікувати тип організаційної культури, оскільки вона зазвичай поєднує елементи різних теоретичних моделей: інноваційної, бюрократичної, демократичної, командної (групової), орієнтованої на результат, агресивної, спрямованої на людину (людиноцентрична), професійної (академічна) тощо [6].

На сучасному етапі реалізації реформ публічного управління в розвитку організаційної культури в державних органах необхідно забезпечити умови для запровадження змін та імплементації інновацій. Тому формування організаційної культури передбачає такі заходи: 1) перехід від забюрократизованих кадрових систем до людиноцентричних, заснованих на досвіді моделей; 2) поширення серед персоналу візії бажаного майбутнього та віри в нього; 3) розвиток дистрибутивного лідерства та запровадження концепції залучення персоналу; 4) забезпечення «підтримуючої автономії» для фахівців, наділення їх повноваженнями ухвалювати рішення в межах визначеної політики, реґламентів і компетентності; 5) створення сприятливого для навчання і розвитку персоналу середовища через формування підтримуючої політики і систем, відведення часу на його здійснення; 
6) визнання важливості демонстрації керівниками рольових моделей; 7) підтримка фахівців у подоланні викликів, надання їм часу, ресурсів і зворотного зв'язку; 8) використання технологій наставництва і коучингу з метою розвитку талантів, заохочення працівників визначати альтернативи і знаходити власні шляхи вирішення проблем; 9) перехід від жорсткого контролю за використанням робочого часу до створення можливостей для альтернативної зайнятості, що зумовлює необхідність удосконалення інструментів управління результативністю. У реалізації цих заходів варто вдосконалювати традиційні інструменти для публічного сектора, а також імплементувати ті, що довели свою ефективність у приватному секторі, зокрема такі, як: HR-брендинг (брендинг роботодавця); гнучкі умови роботи; системи навчання і розвитку персоналу, які передбачають можливості для розвитку талантів; програми добробуту працівників; нові системи винагород, які, на думку експертів міжнародного кадрового агентства «Делойт», мають бути персоналізованими, комплексними і гнучкими, а тому орієнтуватись на індивідуальний внесок працівників та формуватись відповідно до їхніх потреб і стилю життя [7]. Необхідність такого підходу підтвердили результати дослідження компанії «Глобофорс», які свідчать, що працівники, які отримують невеликі, проте регулярні винагороди у формі грошей, балів або подяк, працюють у 8 разів активніше, ніж ті, хто отримують компенсацію і бонуси раз на рік [8]. Незважаючи на це, схвалена Урядом у травні 2020 р. нова Концепція реформування системи оплати праці державних службовців [9] передбачає скасування таких видів виплат, як місячна премія і надбавка за ранг. На нашу думку, такий підхід може знизити ризик зловживань, однак не сприятиме запровадженню системи управління результативністю на постійній основі.

Отже, проблеми розвитку людських ресурсів та організаційної культури в державних органах є складними, слабо структурованими, a їх вирішення не забезпечено релевантними даними для публічного сектора. Для вирішення таких проблем у структурах урядів або HR-агентств США, Великої Британії, Канади, Фінляндії, Швейцарії, Сінгапуру, Австралії, Китаю, Данії та інших країн створено дизайн-лабораторії (центри досконалості), у яких на основі поєднання досвіду науковців, експертів та публічних службовців забезпечується пришвидшення змін, орієнтованих на підвищення продуктивності робочої сили, розвиток організаційного лідерства, нарощення потенціалу, створення інноваційної та відпові- дальної публічної служби на основі проєктного підходу та методології дизайн-мислення.

Дизайн-мислення - це комплексний підхід, який забезпечує створення нового концепту продукту чи послуги шляхом визначення й аналізу прихованих і незадоволених потреб споживачів, генерування і розвитку креативних ідей, їх візуалізації та тестування для подальшого впровадження якісних змін.

Нині важливим індикатором ефективності функціонування державних органів є не тільки надання якісних адміністративних послуг, а й розвиток власного персоналу, повернення сенсу в його роботу. Тому ми пропонуємо почати запроваджувати методологію дизайн-мислення в державних органах саме з розвитку їхньої організаційної культури на основі таких принципів, як:

- людиноцентризм, коли відправною точкою є визначення потреб і мотивів працівників, а не встановлення їм планових показників (необхідно з'ясувати, що вони роблять і чого не роблять, що говорять і чого не говорять, що було зроблено і що не спрацювало);

- інкременталізм у вирішенні складних проблем, який сприяє поступовому запровадженню змін та інновацій (наприклад, удосконалення системи мотивації персоналу, підходів до його оцінювання, навчання і розвитку тощо замість спроби модернізувати систему організаційної культури шляхом запровадження однієї складної довгострокової зміни);

- формування проєктних команд експертів із різних сфер - гуманітарної, соціальної, економічної, юридичної, інформатики тощо (оптимальна кількість - 6-9 осіб), яким притаманні такі якості, як емпатія, інтегративне мислення, аналітичні здібності, оптимізм, здатність експериментувати та взаємодіяти, розвинута інтуїція, а також раціональність;

- ітеративність дизайн-процесів, чітке розмежування стадій визначення проблеми та її вирішення;

- орієнтація на пошук нових альтернативних рішень, принципово відмінних від тих, які не забезпечили вирішення наявних проблем (на ранніх стадіях їхня кількість є важливішою за якість);

- послідовне застосування дивергентного та конвергентного мислення;

- використання холістичного й експериментального підходів із метою врахування впливу зовнішніх і внутрішніх чинників та зниження ризиків уже на ранніх стадіях (важливою умовою реалізації цих підходів є толерування «швидких невдач» на ранніх етапах);

- орієнтація на досягнення SMART-цілей, оцінювання їх реалізації з урахуванням зворот- 
ного зв'язку від цільової аудиторії (у даному разі - персоналу державного органу);

- створення спеціального середовища для зручної роботи мультидисциплінарної команди, її оснащення необхідними засобами;

- чітке дотримання часових обмежень, визначених для кожного етапу дизайн-процесу (особливо це важливо для збору інформації);

- розроблення максимально спрощених, але водночас змістовних прототипів (від ескізів та макетів до комп'ютерних програм) для швидкого тестування нових ідей та рішень.

Зазначені принципи свідчать, що методологія дизайн-мислення $€$ широкою і гнучкою концепцією, інтегрує три основні складові частини: 1) спосіб мислення, який ґрунту- ється на людиноцентричному підході, поєднує дивергентне і конвергентне мислення; 2) реґламентований ітераційний процес вирішення проблеми через розроблення та тестування інноваційного рішення (рис. 1); 3) поєднання набору методів із різних дисциплін (менеджмент, маркетинг, соціологія, економіка, право, інформатика, психологія тощо).

На рис. 1 відображено схему процесу використання методології дизайн-мислення, яка у вирішенні проблеми низької ефективності системи навчання і розвитку персоналу (як важливої складової частини організаційної культури державного органу) передбачає виконання таких процедур.

На першому етапі необхідно з'ясувати, у чому полягає проблема, яка цільова аудито-

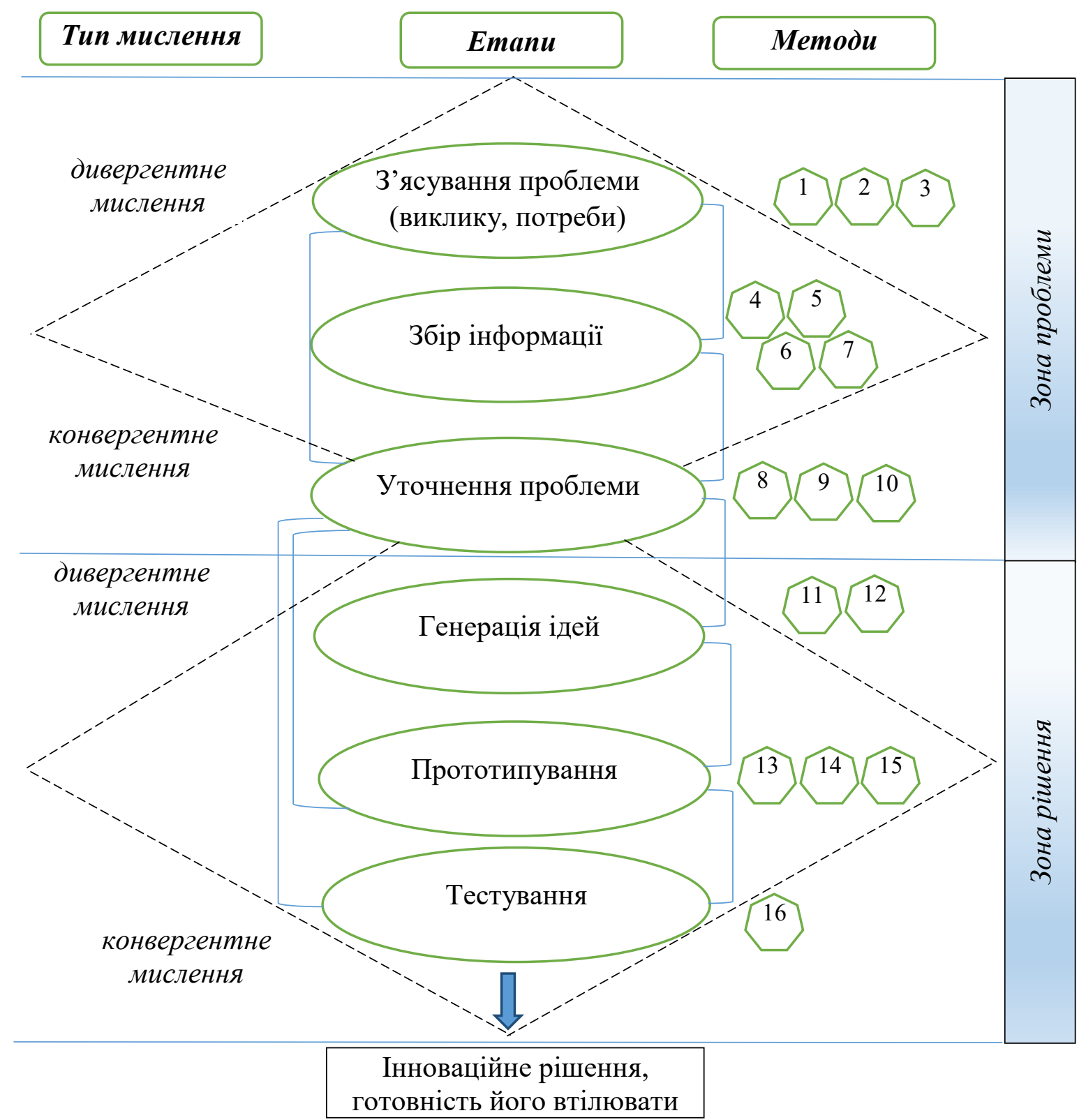

Рис. 1. Процес використання методології дизайн-мислення 
рія (у розрізі категорій посад, досвіду роботи на державній службі, вікових категорій персоналу, структурних підрозділів чи функціоналу тощо), що необхідно для підвищення ефективності системи навчання і розвитку. Для вирішення цих завдань доцільно використати такі методи:

1) матрицю відомого й усвідомленого стосовно визначеної проблеми, яка складається із чотирьох частин: усвідомлені знання; неусвідомлені знання, які чомусь не використовуються; усвідомленні незнання з певних питань; неусвідомлені незнання - так звані «білі плями». Остання складова частина - це те, де починається дизайн-мислення [10, с. 15];

2) дерево проблем, яке дозволяє проаналізувати основні причинно-наслідкові зв'язки ситуації;

3) метод " 5 W" (Who? What? When? Where? and Why?) дозволяє заглибитись у проблему за допомогою відповідей на запитання: Хто має проблему? У чому суть проблеми? Коли виникла проблема? Де виникла проблема? Чому конкретна ситуація є проблемною? [10, с. 14]. Число $5 €$ умовним, запитань може бути значно більше.

На другому етапі проводиться збір інформації з використанням таких методів:

4) інтерв'ювання працівників 3 питань їхнього навчання і розвитку;

5) обстеження створених умов, середовища, вивчення організаційних реґламентів та інших документів;

6)складання «карти емпатії» працівників, яка допомагає проаналізувати, що вони думають і відчувають, бачать, чують, говорять і роблять, якими є їхні страхи, проблеми та цінності;

7) складання «карти подорожі» працівників стосовно їхнього навчання і розвитку, від виявлення потреб у навчанні до моменту впровадження набутих знань і вмінь у професійну діяльність.

На третьому етапі здійснюється уточнення проблеми на основі одержаної інформації, для систематизації якої використовуються такі методи:

8) сторітеллінг;

9) кластеризація інформації з розмежуванням релевантних і нерелевантних даних;

10)дискусія.

На четвертому етапі генерація ідей проводиться за принципом «кількість важливіша за якість». Основними методами цього етапу є такі:

11) мозковий штурм;

12) ранжування ідей за обраними критеріями.
На п'ятому етапі здійснюється візуалізація ідей шляхом розроблення максимально спрощених прототипів із використанням таких методів, як:

13) тривимірне моделювання;

14) рольова гра;

15)сторіборд (представлення сценарію у вигляді послідовних кадрів).

На шостому етапі відбувається тестування прототипів у послідовності, визначеній відповідно до їх ранжування з використанням методу:

16) експеримент.

Процес дизайн-мислення дуже рідко буває лінійним, адже можуть скластися ситуації, коли на етапі прототипування чи тестування з'ясовується, що не всі потреби працівників було ідентифіковано, або, наприклад, проблема, яку необхідно вирішувати насамперед, насправді полягає в низькій мотивації персоналу або неправильному визначенні освітніх потреб на підставі суб'єктивних оцінок результатів службової діяльності тощо.

Запропонований алгоритм використання методології дизайн-мислення у вирішенні проблеми низької ефективності системи навчання і розвитку персоналу державного органу було обговорено із працівниками Міністерства юстиції України під час проведення вебінарів із питань запровадження змін та управління персоналом (3-4 та 14-15 вересня 2020 р.). Після завершення навчання слухачам було запропоновано висловитись щодо доцільності запровадження методології дизайн-мислення для запровадження змін із використанням онлайн-опитувальника Mentimeter.

В опитуванні взяли участь 96 осіб (державні службовці, посади яких віднесено до категорій «Б» та «В»), з яких 79 осіб (82,3\%) зазначили, що дизайн-мислення доцільно використовувати в органах влади, 17 осіб $(17,7 \%)$ вагались та не змогли дати однозначної відповіді (адже дистанційний формат дозволяє лише ознайомитись із методологією та, на жаль, не сприяє опануванню іï), але жоден із респондентів не дав негативної відповіді. Серед основних бар'єрів запровадження методології дизайн-мислення в державних органах респонденти відзначили такі, як бюрократія, низький рівень мотивації та готовності державних службовців до змін, відсутність лідерів та необхідних знань, брак часу, недостатність фінансування. Тому 3 метою реалізації пілотного україно-литовський проєкту «Розвиток компетентності працівників литовського та українського публічних секторів із використанням методології дизайн-мислення» Івано-Франківський національний тех- 
нічних університет нафти і газу ініціюе створення дизайн-лабораторії "LIDER" (Laboratory of Intellectual Development for Empowering Regions - Лабораторія інтелектуального розвитку для посилення спроможності регіонів) на базі Інституту гуманітарної підготовки та державного управління.

Висновки. На сучасному етапі реалізації системних реформ публічного управління у формуванні організаційної культури, сприятливої для розвитку людських ресурсів е державних органах, необхідно використовувати інструменти, які довели свою ефективність у закордонній практиці, - HR-брендинг, системи навчання і розвитку персоналу (зокрема, розвитку талантів), гнучкі умови роботи, програми добробуту працівників, гнучкі системи винагород тощо. Передовий іноземний досвід та результати опитування державних службовців Міністерства юстиції України свідчать, що в ухваленні рішення щодо адаптації цих інструментів доцільно використовувати методологію дизайн-мислення, яка $€$ ефективною людиноцентричною соціальною технологією, орієнтованою на впровадження якісних змін шляхом підготовки та тестування інноваційних рішень на підставі комплексного вивчення потреб цільової аудиторії, а також формування готовності їх утілювати.

\section{ЛІТЕРАТУРА:}

1. Handbook of research on organizational culture and diversity on the modern workforce / edited by B. Christiansen, H.C. Chandan. Hershey : Business Science Reference, 2017. 421 p.

2. Staack V., Cole B. Reinventing innovation: five findings to guide strategy through execution. PricewaterhouseCoopers innovation benchmark, 2017.
URL: https://www.pwc.com/gr/en/publications/assets/ innovation-benchmark-report.pdf.

3. Звіт за результатами опитування щодо булінгу на державній службі (березень квітень 2019 р.). НАДС : офріційний сайт. URL: https://nads.gov.ua/storage/app/sites/5/human\%20 resourses/22.pdf.

4. Результати опитування працівників служб управління персоналом державних органів щодо виявлення потреб отримання методологічної допомоги з питань управління персоналом у державних органах (листопад 2018 р.). URL: https://nads.gov.ua/ storage/app/sites/5/human\%20resourses/31.pdf.

5. Формування нової корпоративної культури в умовах реалізації ресоорми місцевого самоврядування та розвитку міжмуніципального співробітництва / за заг. ред. Н. Щербак, Т. Журавля, В. Толкованова. Київ : Фенікс, 2018. 156 с.

6. Орлів М., Онищук С. Менеджмент людських ресурсів : конспект лекцій. Івано-Франківськ : Місто $\mathrm{HB}, 2020.140 \mathrm{c}$.

7. Нові системи винагород 2018 / ТОВ «Делойт i Тyш». URL: https://www2.deloitte.com/content/ dam/Deloitte/ua/Documents/human-capital/DeloitteGlobal-Human-Capital-Trends-2018-Statistics-byUkraine-3.pdf.

8. Designing work cultures for the human era : The 2018 SHRM. Globoforce employee recognition report. URL: http://go.globoforce.com/rs/862-JIQ-698/images/ SHRM2017_GloboforceEmployeeRecognition ReportFinal.pdf?_ga=2.124440207.402124214. 1584785526- 684513056. 1584785526.

9. Про схвалення Концепції реформування системи оплати праці державних службовців : розпорядження Кабінету Міністрів України від 27 травня 2020 p. № 622-p. URL: https://www.kmu.gov.ua/npas/ pro-shvalennya-koncepciyi-reformuvannya-sistemioplati-praci-derzhavnih-sluzhbovciv-ta-zatverdzhennyaplanu-zahodiv-z-yiyi-realizaciyi-i270520-622.

10. Müller-Roterberg C. Handbook of design thinking : Tips \& tools for how to design thinking. Amazon Digital Services LLC - Kdp Print Us, 2018. 228 p. 